\title{
The Constitutional Identity of the Public Budgeting on the Scale of the European Union and Optimum Constitutional Budgeting
}

\author{
Mehmet Alpertunga Avci, Assist. Prof. \\ Atatürk University, Faculty of Law Department of Fiscal Law \\ maavci@atauni.edu.tr
}

\section{Doi:10.5901/mjss.2015.v6n2s2p131}

\begin{abstract}
The public budgeting, that allows collecting revenues and performing expenditures for a certain period and provides effective legislative audit and supervision, has established itself within the constitutions. In this way, the power of the purse is guaranteed constitutionally. However beyond the power of the purse, new and modern guarantees should be planned into the constitutions due to the profound effects of the public budgets on the economic life. There is needed a constitutional budgeting, considers citizen choices, in behalf of minimizing negative effects of public budgeting on the economic life. In this article which is a study on the scale of the European Union (EU), regulations on the public budget in the member country constitutions are examined in the light of the modern budgeting principles and the fiscal constitution approach. In this context this article initially identifies theoretical framework and approaches relating to the budgeting principles and in parallel with the constitutionalism. In the sequel it explores the provisions for public budgeting into the constitutional arrangements of $26 \mathrm{EU}$ countries. Finally it compares country practices, gives suggestions how optimum constitutional budgeting should be done based on the budgeting principles and constitutional order. This article aims to suggest the basic theoretical structure of optimum constitutional budgeting on the scale of EU from the perspective of budgeting principles and constitutional budgeting. The ultimate goal of the article is making suggestion relating to budgeting in the EU constitution making process, to provide instructive and interpretive a discussion base for both scientists and bureaucrats in the light of the EU macro analysis.
\end{abstract}

Keywords: Public Budgeting, The Power of the Purse, Economic Constitution, Constitutional Budgeting, Public Choice.

\section{Introduction}

Public budgeting is one of the basic tools both constitutional order and democratic regimes, in the modern era. Particularly public budgeting draws the fiscal and financial limitations of the mutual duties and responsibilities of the executive and legislative branch within the framework of the relationship between political power and sovereignty. From this aspect it is impossible to isolate the budgets from constitutions and constitutional orders. If it is expected to talk about a modern democratic constitutional order, there is needed a public budget as well. In that case what is understood from the public budgeting? In public budgeting there are basically three main questions. First question is "who pay the tax?", the second one is "who make the decisions?" and final question is "how the money will be spent?". Within the framework of these questions, there are two groups emerge as part of public budgeting: taxpayers and decision makers. Due to the fact that public budgeting tell citizens how well their money is being spent by the decision makers (Rubin, 1997, p. 191).

Today little has been written on the relation of public budgeting to the formulation of public policy in a democracy. This determination has been due to the relatively short history of responsible budgeting in today's public finances (Steiss, 1972, p. 292). However modern democracies expect public budgeting to do a number of different tasks about public policy, particularly in this era. These expected tasks are setting of goals and priorities, linking goals to actions, managing the economy, promoting accountability, controlling the use of public resources, promoting efficiency and effectiveness, promoting social planning and reform, and keeping the process manageable in government therefore in public sector. Through these tasks public budgeting can be used to help a government making progress toward social goals. An understanding in keeping with this goal is found in public choice theories and in welfare economic approaches. Public budgets are not only a central function but also a political process that should influence the whole administrative structure. As a political process public budgeting allows for decision makers give shape the budget to fit their preferences (Nice, 2002, p. 3-4-5-6-8; Willoughby, 2014, p. 21). In this respect, if the public budgeting will be considered as a political process the executive branch has normally and directly been responsible for this process (Nice, 2002, p. 36). The legislative branch has the power to conduct the follow-up of this responsibility in the democratic process. Constitutions, as the basic legal regulations, will achieve public budgets from these tasks and goals and ensure the political process 
between the legislative and executive branches. However each government has its own constitution, depending on the legal system and many state constitutions contain budgetary provisions according to their requirements (Nice, 2002, p. 97). This situation makes it difficult to reach a universal consent optimum constitutional budgeting. In the light of these information firstly it is necessary to explain constitution and constitutional terms; to present modern budgeting principles in order to reach an optimum constitutional budgeting. Secondly it should be browsed to the EU country constitutions in the light of the modern budgeting principles.

\section{Constitutionalism as a Guarantee for Responsible Budgeting}

In the modern world, constitutionalism is regarded as one of the guarantor factor of the modern public budget systems and budgeting principles. In spite of the fact that constitutionalism does not have a stationary character. As a dynamic system, constitutionalism requires the presence of many organizational structures and several technical concepts in order to sustain its existence. In this respect it is necessary to present the general principles of the state, political power and sovereignty, democratic regime, and rule of law in order to comprehend the institutional and conceptual importance of the constitutional order and the constitutional budgeting. In spite of the fact that the state means rule of law and the rule of law is also provided by the constitution. The constitution makes sense within the framework of the rule of law (Özer, 2010, p. 8; Kaboğlu, 2014, p. 2).

\subsection{State, Political Power and Rule of Law}

With a simple definition, the state is an artifact legal and political organization. It is furnished with authority and has rights and duties apart from the administrators and individuals (Kaboğlu, 2014, p. 1-59-74; Teziç, 2014, p. 159). With the development of the welfare state approach, it has become necessary to go beyond the protection of the institutional order. The welfare state, reflected in constitutions as the concept of the social state, requires the state to take the economic and social development and protection as well (Kaboğlu, 2014, p. 102-103). From this aspect in order to ensure social peace and justice the social welfare state finds the intervention of the state necessary in economic and social life. However, this interventions should be in a systematic, coherent, rational, and scientific manner (Özbudun, 2014, 140-152). In our era, state concept has not limited to the social welfare state approach. Indeed, in the 1970s functional state approach and in the 1980s neoliberal approach have reshaped the modern state (Kaboğlu, 2014, p. 103104).

According to the classical democratic theory the state is based on power and the nation is a direct source of this power and the sovereignty. In this respect state needs the political power, which delivers the state on its objectives, in order to use sovereignty. The political power can be described as the legislative power and right which aims to protect and regulate the ownership for the public benefit (Esen, 1957, p. 63-64; Gözübüyük, 2013, p. 16-72). Political power should be accepted by the society and suitable to the law, and gives direction to society in order to mention the presence of political power in the state (Gözübüyük, 2013, p. 16-17). Democracy is the dominant political doctrine of the modern world. In this context government system should be democratic regime in a state where sovereignty and political power is dominant (Özbudun, 2014, p. 89-90).

Particularly in democratic regimes, political power should be regulated in accordance with the law. Likewise the state is available by means of the law (Teziç, 2014, p. 162-163). With this aspect the principle of the rule of law -one of the main elements of the all civilized democratic regimes- come into prominence. The rule of law is a system where the citizens have the legal security and the state comply with the legal rules in a body (Özbudun, 2014, p. 125). Therefore bodies that exercises state authority can use lawful instruments and act as prescribed by law. In a rule of law, legal rules should be known and legalism should be secured with the legal sanctions. In spite of the fact that it aims to prevent the arbitrary behavior of the managers and any official institution and authority, and authorized person cannot go beyond the rule of law (Teziç, 2014, p. 162; Kaboğlu, 2014, p. 17-18).

\subsection{Constitutional Order}

As a result of the principle of the rule of law, legislator should use the power granted by legal regulations within the constitutional limits and in consideration of the justice, equity and public welfare criteria (Özbudun, 2014, p. 126). In a pluralistic democracy the plurality should be limited to the constitution as well. So that the plurality is also provided to act in accordance with the law (Gözübüyük, 2013, p. 26-27). Constitutions which is the requirements of the principle of the rule of law have the identity of being a document that limits the political power within the state (Teziç, 2014, p. 4-160). In 
this respect, constitution can be defined;

"... as sites of negotiation and contest, in order to emphasize the inherent dynamics of norms, intentions, and effects that accompany attempts to anchor and secure visions of social order and justice through a rule-establishing textual form (Gortke, Prutsch, 2014, p.18)".

This textual forms have a social contract identity between the state and the citizens. In other words the constitution belongs to the whole people of a country and it can draw its legitimacy only from a social and broad participation agreement of the whole citizens (McLeay, 2011, p. 4). From this aspect constitutions -accepted as a legal and political texts- indicate the rules governing the basic structure, organization, and functioning of the state. They are the fundamental principles guiding the political power in the social and economic fields (Gözübüyük, 2013, p. 3; Grotke, Prutsch, 2014, p.18).

As a rule, every state has a constitution today and any constitution will be completely the same as another one (Teziç, 2014, p. 159; Parpworth, 2014, p. 8). Today, constitutions are classified as written or unwritten, flexible or inflexible, monarchical or republican, parliamentary or presidential, federal or unitary, quantitative or qualitative constitutions (Parpwort, 2014, p.7-8).

State and constitution is necessary condition of each other. Likewise each state has an order and it is called as "constitutional order". From this aspect constitution sets the framework of the state life (Gözübüyük, 2013, p. 12). Constitutions should be superior to all other legal rules as a ground norm and the highest legal rule in order to give life to society's main institutions (Özer, 2010, p. 10; Kaboğlu, 2014, p. 42, Gözübüyük, 2013, p. 10). In other words;

"where a constitutional document does exist, it represents a form of law superior to all other laws in the state (Parpworth, 2014, p. 4)".

It is called as "The Supremacy of the Constitution". The supremacy of the constitution is one of the basic principles of the liberal world-view (Teziç, 2014, p. 166). Constitutional provisions binds legislative, executive and judicial organs and administrative authorities and individuals as a result of the supremacy of the constitution (Özbudun, 2014, p. 39).

\subsection{Constitutional Order}

As a result of the principle of the rule of law, legislator should use the power granted by legal regulations within the constitutional limits and in consideration of the justice, equity and public welfare criteria (Özbudun, 2014, p. 126). In a pluralistic democracy the plurality should be limited to the constitution as well. So that the plurality is also provided to act in accordance with the law (Gözübüyük, 2013, p. 26-27). Constitutions which is the requirements of the principle of the rule of law have the identity of being a document that limits the political power within the state (Teziç, 2014, p. 4-160). In this respect, constitution can be defined;

"... as sites of negotiation and contest, in order to emphasize the inherent dynamics of norms, intentions, and effects that accompany attempts to anchor and secure visions of social order and justice through a rule-establishing textual form (Gortke, Prutsch, 2014, p.18)".

This textual forms have a social contract identity between the state and the citizens. In other words the constitution belongs to the whole people of a country and it can draw its legitimacy only from a social and broad participation agreement of the whole citizens (McLeay, 2011, p. 4). From this aspect constitutions -accepted as a legal and political texts- indicate the rules governing the basic structure, organization, and functioning of the state. They are the fundamental principles guiding the political power in the social and economic fields (Gözübüyük, 2013, p. 3; Grotke, Prutsch, 2014, p.18).

As a rule, every state has a constitution today and any constitution will be completely the same as another one (Teziç, 2014, p. 159; Parpworth, 2014, p. 8). Today, constitutions are classified as written or unwritten, flexible or inflexible, monarchical or republican, parliamentary or presidential, federal or unitary, quantitative or qualitative constitutions (Parpwort, 2014, p.7-8).

State and constitution is necessary condition of each other. Likewise each state has an order and it is called as "constitutional order". From this aspect constitution sets the framework of the state life (Gözübüyük, 2013, p. 12). Constitutions should be superior to all other legal rules as a ground norm and the highest legal rule in order to give life to society's main institutions (Özer, 2010, p. 10; Kaboğlu, 2014, p. 42, Gözübüyük, 2013, p. 10). In other words;

"where a constitutional document does exist, it represents a form of law superior to all other laws in the state (Parpworth, 2014, p. 4)". 
It is called as "The Supremacy of the Constitution". The supremacy of the constitution is one of the basic principles of the liberal world-view (Teziç, 2014, p. 166). Constitutional provisions binds legislative, executive and judicial organs and administrative authorities and individuals as a result of the supremacy of the constitution (Özbudun, 2014, p. 39).

\subsection{Fiscal Constitution and Economic Constitution}

The state organically is in a continuous growth and as a natural consequence of this growth, constitutions should be more sophisticated and capable (Gözübüyük, 2013, p. 18). At the same time, in the process of the historical development, neoliberalism and socialism have a direct effect of the spirit of the constitution. The contemporary constitutionalism which is affected by the neoliberal doctrine gave wide and direct publicity to the economy policy into the constitutions. As a requirement of the rule of law constitutions should be relatively neutral in the face of the economic policies that are affected by the political preferences of political power (Kaboğlu, 2014, pp. 2-8 \& p. 140; Özbudun, 2014, p. 143).

Today's modern constitutions have an original identity with political, social and fiscal aspects. In a political and social sense state establishes the main organs, regulates the functioning of the power and social rights and liberties within the society. It is necessary to browse the concept of the fiscal constitution in order to reveal the financial aspects of the constitutions. Fiscal constitutionalism -emerged in Germany after the Second World War- describes the mechanisms envisaged by the constitution and related to the public finance. Therefore it adds a constitutional value in order to ensure the economic and fiscal stability, and reveals the behavior of the economic actors (Kaboğlu, 2014, p. 14).

In the framework of the public finance there is a number of key areas of economic management consisting of public budgeting, taxation and borrowing, fiscal and monetary policy, public enterprises, and public procurement and expenditures. These instruments regulates the public fiscal management as a whole and they are used by government to achieve fiscal and economic goals. As a technical matter the use of public resources and expenditures are closely connected with the policy goals of the executive in an economic management. These matters gain legitimacy through a combination of electoral succession and political responsibility. Likewise a public authority gains its legitimacy from the political process. As a result of this, a public authority should ensure fiscal transparency, transparent political process, and budget process and principles constitutionally (Prosser, 2014, pp. 2-7). In this respect there is needed to browse to the constitution which is the source of the legitimacy and the political power in the light of the economic constitution concept.

Tonny Prosser has characterizes economic constitution as follow:

"Economic constitutions are at one level mapping documents; they set out the key state institutions, their interrelations, and their relationship with civil society. They also permit effective governance and the coordinated development and implementation of public policy (Prosser, 2014, p. 7)."

In the light of this characterization Prosser tackles this issue in different ways. Firstly economic constitution relevant for the economic management. Likewise in many countries constitutions in relation to public revenues, expenditures, and property rights. Secondly economic constitution is associated with 'ordoliberalism'. According to the ordoliberalism economic constitution highlights the primacy of politics over economics (Somma, p.8-109). For the Prosser quoted from David Gerber:

\footnotetext{
"the ordoliberals added a 'constitutional dimension' to their analysis of economic problems. A community's political constitution and its choices in using law to implement that constitution, they said, must ultimately establish the characteristics of its economic system. Economic systems did not just 'happen'; they were 'formed' through political and legal decision-making. These fundamental choices determined a nation's economic constitution.... (Prosser, 2014, p. 89)".
}

Form this aspect economic constitution can be regarded as a prior and key consideration of the new economic management philosophy and it is directly affect the political choices. Accordingly it is predicted that this type pf philosophy brings us to the public choices. Thirdly according to the Prosser, economic constitution can be evaluated as a set of social values in the economic management process. Finally economic constitution is one of the product of 'new constitutionalism" (Prosser, 2014, p. 10).

\section{Modern Public Budgeting Principles}

In order to mention about a modern constitution, as a supreme and basic legal regulation, should be designed in 
accordance with the fiscal and economic constitution philosophy. This philosophy gives the character to constitutions being the main directory of public finances. In this regard public budgeting, one of the most important instruments of public finances, unthinkable outside the constitution. Modern budgeting principles which are the constituent elements of the public budget should take place within the constitutions in order to provide constitutional assurance for the public budgeting. A matter of fact, public budgeting which is a requirement of the rule of law is the constituent and fundamental element of power and dominance relations.

Modern public fiscal managements should take a variety of budgeting principles into consideration in order to implement the conventional and modern functions of the public budgeting. These principles have a great importance for the usage of the power of the purse. In this context these principles are observed starting with the process of preparation of the public budgeting and the discharge of the budget execution. These principles which have been developed in parallel with the development of parliamentary democracy are allow to obtain reliable and complete information about the estimation of the public revenues and expenditures. In this respect budgeting principles can be defined as a set of rules that must be followed in the budget process. However it should be emphasized that the presence of these principles are not indisputable. In this respect these principles can be differ from both in different periods within the same country and in different countries in the same period (Altuğ, 1999, p. 12-13-14; Tüğen, 2005, p. 31; Aksoy, 1993, pp. 111-138). In the light of these preliminary information budgeting principles can be listed in ten titles.

a) Principle of Publicity (PP): This principle is called by different names such as publicity, transparency, openness, publicity, accuracy etc. It is basically enable to public scrutiny (O'Regan, 2004, p. 259). According to PP public budgeting should be conducted in the open (Willoughby, 2014, p. 20). In this respect PP can be defined as a disclosure and publication activity about all information and documentation related to the budget process. According to the budget process it informs decision-makers about the real financial situation of the public fiscal administration. All related financial statements and documents should be published regularly in order to protect PP. In spite of the fact that citizens, tax payers and other third parties such as international credit rating agencies, international financial institutions, and lender countries want to be inform about budget process. In addition to all these information PP serves the purpose of ensuring accountability in public fiscal management. From this aspect PP gives an opportunity to criticize and analyze the executive through the public budgeting. So that the power of the purse would be used effectively by the citizens (Tüğen, 2005, p. 43; Mutluer- Öner-Kesik, 2006, p. 97-98; Feyzioğlu, 1981, p. 49; Altuğ, 1999, p. 25).

b) Principle of Clarity (PC): As a technical document public budgets are distinctive in that it is subject to a large number of rules, regulations, and procedural guidelines that make the process quite complex (Nice, 2002, p. 3). Governments spending's share in GDP has increased steadily as well. Depending on these factors public budgets has become confusing, because it has a language of its own that many people do not understand. However it cannot be expected from each citizen and deputy to understand and evaluate these kind of technical documents as a budget expert. In this respect public budgets should be brought in clear. This also brings us to the principle of clarity (Mutluer- Öner-Kesik, 2006, p. 97-98; Nice, 2002, p. 2). According to PC, also accepted as one of the seven principles of public life, the information in a public budget should be understandable (O'Regan, 2004, p. 198; Willoughby, 2014, p. 20). In order to achieve this principle definitions related to income and expense should be very clear and precise, classification of income and expenses should be in accordance with scientific principles and rule of logic (Edizdoğan et al., 2011, p. 425).

c) Principle of Accuracy (PA): This principle, aims the revenues and expenditures estimates should be correct (Willoughby, 2014, p. 20), consists of subjective and objective accuracy principles. In this context Subjective Accuracy Principle (SAP) is also known as the principle of sincerity. The administration which is responsible for preparing the public budget should show the actual shape of the estimated revenue and expenses as a requirement of SAP. In this respect revenue and expense estimations must be in accordance with the actual needs and circumstances. Accordingly budget administration must not deviate from the real needs and expectations for the sake of ensuring seemingly equivalence in the budget. According to the Objective Accuracy Principle $(O A P)$, revenue and expenditure estimations should be appropriate to the real economic conditions. OAP cannot be mentioned in case of the extremely optimistic or pessimistic estimations (Feyzioğlu, 1981, p. 48; Altuğ, 1999, p. 26).

d) Principle of Annualization (PAN): This principle can be defined as the restatement of an item to reflect a one year period. PAN is common in fiscal planning, which often require external evaluation of revenues and expenses to cover a full fiscal year. (O'Regan, 2004, p.18). In other words the budget is applied for a specific period of time and this time period is usually one year (Tüğen, 2005, p. 42). With this principle both revenue and expenses estimates can be made in true manner and the power of the purse can be used effectively by 
the legislature. Therefore PAN is one of the adopted and accepted budgeting principle by many countries (Aksoy, 1993, p. 220-221).

e) Principle of Allocation of the Expenses (AE): This principle is relating to the identification of revenues or expenses with specific activities, assets, services, limits, or time periods. AE can be used to refer to the division of revenues and expenses between various items as well (O'Regan, 2004, p. 15). In this respect AE is divided into three forms: Principle of Allocation in Terms of Quality (PATQ), Principle of Allocation in Terms of Quantity (PATQU) and Principle of Allocation in Terms of Time (PATT). According to;

- PATQ, the appropriations allocated to certain public services are used only for these services.

- PATQU, spending over appropriations cannot be done.

- PATT, budget authorization is given for a fiscal year (Edizdoğan et al., 2011, p. 424; Altuğ, 1999, p. 27).

f) Principle of Prior Authorization (PPA): This principle basically contains authorization and authorization right. In this context it should be described these terms to grasp the importance of the PPA. Firstly authorization means that the giving of approval or permission. It is central to many of the fiscal transactions and decisions in modern public fiscal administrations, from the using of the power of the purse (O'Regan, 2004, p. 39). It can be provided for one year, multiple-year, and no-year by the period of availability, currently or permanently by the timing of legislative action or definite or indefinite by the manner of determining the amount available. Authorization incorporates appropriations, borrowing authority and contract authority (Lyden and Lindenberg, 1983, p. 5). Secondly authorization right is one of the most important prerequisites of the power of the purse. Accordingly authorization derive from the status of the legislature, and is restrained by accountability for the exercise of the power of the purse (O'Regan, 2004, p. 39). PPA provides to executive spending directly as well (Lee, et al., 2004, p. 272). On the light of these information PPA can be defined as the direction of the executive authority to make spending and collect revenue granted by the legislature. As a requirement of the democratic governance and pluralistic approach the executive cannot collect any revenue and make any spending without this authority (Aksoy, 1993, s. 220).

g) Principle of Equivalence (PE): According to the principle of equivalence, expenditures may not exceed revenues, but not all available revenues and expenses must be appropriated and spent. PE is not uniform across all governments due to the requirements and achieving to $\mathrm{PE}$ in a public budget is a political process (Lee, et al., 2004, p. 155-156). There are differences between classical and modern budget approach about this principle. According to the classical budget approach -is the product of liberal economic approachexpenses and revenues must be equal in absolute terms and this equivalence must be maintained in any event. However depending on the developments in the economic life, the possibility of providing classical budget equivalence is quite difficult today. In contrast, according to the modern budget approach which is a product of the contemporary public finance it is essential to ensure the economic stability (Tüğen, 2005, s. 4243; Edizdoğan vd., 2011, s. 428-429; Mutluer-Öner-Kesik, 2006, s. 91; Altuğ, 1999, s. 27). Contemporary public finance has put forward to the compensatory budget and cyclical budget theories in order to ensure economic stability. Cyclical Budget Theory propose to ensure the budget equivalence in the economic expansion and contraction terms and it considers the budget equivalence more flexible way. According to this theory taxes should be reduced in order to stimulate the market and public expenditures should be increased at the risk of the budgetary deficit in the period of recession. In the period of inflation the opposite budget policy should be followed to restabilize the economy. In other words in the period of recession governments should follow expansionary fiscal policy and in the period of inflation they should pursue contractionary fiscal policy. Compensatory Budget Theory looks for the elimination of the structural flaws in the economic life. According to this theory the budget equivalence can be achieved when the total demands equals to total supply and this equality is also exceptional. Apart from this exception to eliminate the stress from the depression budget balances should be set aside and governments pursue unbalanced budgetary policy (Edizdoğan et al., 2011, p. 430-431; Mutluer-Öner-Kesik, 2006, p. 92-93-94).

h) Principle of Economy (PEC): In a public sector, PEC can be described as the ratio between planned inputs and actual inputs from the point of unit costs. The aim of this principle is to manage public resources, and to improve of the production and distribution of a public wealth (O'Regan, 2004, p. 100). In this context as a requirement of performance management PEC is intended to provide the highest potential social benefit with an amount of money and efficiency in the public sector, to prevent unnecessary expense, to reduce unit costs and to improve the quality of services (Sönmez, 1994, p. 22; Edizdoğan et al., 2011, p. 426; Altuğ, 1999, p. 27). 
i) Principle of Comprehensiveness (PCO): Principle of universality necessitates that all public revenues, expenditures, and debts completely and fully should be included in the state budget. In order to mention the PCO every sort of public revenues and expenses should be shown in the same budget and the public finance should be considered as a whole (Edizdoğan et al., 2011, p. 394-395; Willoughby, 2014, p. 20; Mutluer-ÖnerKesik, 2006, p. 83-84; Altuğ, 1999, p. 28).

j) Principle of Unity (PU): It is necessary to define the concept of unified budget in order to understand the importance of the PU. In this context a unified budget covering all revenues and expenditures in the public fiscal management. A unified budget strengthening control over the public purse and enforcing accountability and transparency. It provides a complete picture of cash flow in the government, the size of the surplus or deficit and borrowing needs, and provides an opportunity to make long-range planning and programming. PU pursue to combine all revenues and expenditures in one budget related to public economy (Axelrod, 1995, p. 292; Mutluer-Öner-Kesik, 2006, p. 88). In other words in order to talk about PU "all government funds should flow through one general fund, with earmarked and special funds kept to a minimum (Willoughby, 2014, p. 20)".

\section{Constitutional Identity of the Power of the Purse in EU Countries}

In modern democracies public budgeting technically comes to life with the power of the purse. Likewise taxpayers delegate the budget making power to the legislative branch via elections. This power which is the product of public choices is defined by the concept of the power of the purse.

"The 'power of the purse' is a constitutionally established responsibility of parliaments and legislatures in governments around the world and the most important feature of a governmental system. The power of the purse is the ability to generate revenues, decide on taxes, and determine how and where public funds will be spent (Willoughby, 2014, p. 198)".

According to this definition the power of the purse is the essential constituent element of the constitutional order and the pluralism. In fact as a result of the power of the purse "public budgeting is being carried out in a capitalist, democratic, federal society, or in a socialist authoritarian, national state. In matters whether the form of government is parliamentary or presidential (Rubin, 1997, p. 186)". In order to mention in a democratic governance the power of the purse which is the main source of the political power and sovereignty should be protected by the constitution. In our era there is a close relationship between the constitutional order with the power of purse in the congressional and parliamentary systems. Moreover it is seen that this power is internationalized in a variety of international integration movement. In the modern age The European Union constitutes the most important example of this international movements. It is seen that there is no a harmony between the member states -particularly at the point of constitutional arrangements for the public budgeting- although the EU seen as an example of good practice in the direction of internationalization. Nowadays, when the EU Constitution is being discussed, this disharmony is strongly threatening the existence of this integration movement. In fact, at the point of reaching an optimum constitutional budgeting, it is primarily important that the EU should be resolved in a fiscal structure drawing strength from the concept of sovereignty, political power, and pluralism in terms of both member states and the EU. In this respect entire modern budgeting principles should be guaranteed in the constitution of each member state. This guarantee is vital for the EU constitution which is anticipated to entry into force.

In the light of the information above it will be useful to look at the 26 member state constitution in the context of the modern budgeting principles*. The EU member state constitutions that are subject to this article can be evaluated as having a written, formal, and parliamentary constitutional structure as a whole. Apart from this generalized evaluation, Belgium, Denmark, Luxemburg, Netherlands, Spain and Sweden constitutions have a monarchial and all other constitutions have a republican character. In the meanwhile it can be done a distinction between these constitutions in terms of the federal or unitary state as well. According to these distinction Austria, Belgium, and Germany constitutions are in a federal and all other constitutions are in a unitary manner.

In addition to this classification within the scope of constitutionalism, it would be useful to assess of these constitutions in a fiscal constitutional manner. Different from the other member state constitutions, Finish, German, Austrian, and Hungarian constitutions incorporate detailed provisions on economic and fiscal issues. In this respect, mentioned constitutions can be accepted as the modern examples of the fiscal constitutionalism. Particularly these

\footnotetext{
* United Kingdom and Cyprus has been excluded from the scope of this article due to the fact that an absence of a formal constitution in United Kingdom and lack of a component political union in Cyprus. 
constitutions have given a detailed place to the legal processes relating to the transfer appropriations, supplementary and extraordinary appropriations, and provisional budgets throughout the public budgeting. As a unique practice Hungarian constitution has brought a significant provision in terms of the constitutional assurance of the public budgeting. According to this provision, stated in Article 37, as long as the state debt exceeds half of the GDP, the Constitutional Court may, within its powers, review the Acts on the central budget, the implementation of the central budget, central taxes, duties and contributions, customs duties and the central conditions for local taxes. According to the Italian, Latvian, Esthon, Portugal, and Slovak constitutions public budgeting should not be subject to referendum, in order to ensure the fiscal discipline and safety.

When the EU member states constitutions discussed in terms of the modern budgeting principles the following conclusions emerges (Table 1):

- In the Czech Republic constitution, there is no provisions that imply the budgeting principles.

- It is often given place to the principle of prior authorization, annualization, and comprehensiveness in the member states constitutions.

- Principle of;

- publicity is located in Austria, Belgium and Hungry constitutions;

- clarity is located in Hungary constitution;

- accuracy and economy is located in Austria and Hungry constitutions;

- allocation of the expenses is located in Germany and Hungary constitutions;

- equivalence is located in Austria, Germany and Hungary constitutions;

- unity is located in Germany and Romania constitutions.

\section{Discussion and Conclusion}

Public budgets are accepted as the basic fiscal tools of the public choices in democratic regimes. Citizens are informed that where their taxes are being used and decision makers are also realized their policies, by means of the public budgeting. There are several administrative, legal, political and social functions of the public budgeting, in modern era. Therefore when public budgets are being prepared, some basic criteria should be taken into consideration by the executive branch. Through these criteria, defined as the budgeting principles, citizen choices and expectations are secured, public resources are used effectively by policy makers, fiscal discipline is ensured, and third parties become aware of the related fiscal system. However these criteria will be binding and meaningful as long as guaranteed by a superior legal regulation. This superior legal regulation is undoubtedly the constitution. Constitution, as a requirement of the principle of the rule of law and a document that limits the political power within the state, stripped its shell and took a fiscal and economic social contract view. These supreme documents are associated with fiscal constitution, constitutional economics, and economic constitution. They have become an impact on the fate of multinational integrations in our era. European integration movements, also known as European Union, is an important example about these integrations. Nowadays, when the EU constitution on the agenda, fiscal aspects of the member states constitutions are not widely opened to discussion. This article was prepared with the aim to lead the discussion from the perspective of the modern budgeting principles and political power, sovereignty, the rule of law, and constitutional order.

In a pluralistic and sovereignty-based constitutional order, public budgeting which is the embodiment of the citizen choices strengthen due to the modern budgeting principles. From this aspect when the EU member state constitutions and budgeting principles discussed as a whole it is mostly observed that the budget processes and legal aspects of the public budgets are passed over before the budgeting principles within the constitutions. Particularly, principle of prior authorization and annualization have been largely able to find a place within the constitutions. However it is quite difficult to say the same thing for the other principles. This situation should not imply that the principle of publicity, clarity, accuracy, allocation of the expenses, equivalence, economy, comprehensiveness, and unity are less important than the principle of prior authorization and annualization. In fact German, Austrian and Hungarian constitutions that described as fiscal constitutions hinders the formation of this bias.

If the EU wants to maintain its presence with a global fiscal modernization approach and the member states aim to harmonize their fiscal systems constitutionally, it is very clear what to do. Modern budgeting principles should be taken a constitutional guarantee even if at the expense of the detailing the constitutions. Constitutional budgeting is a reality and necessity of the modern age. Simply because each country having the aim of democratization should give an importance for the budgeting principles within their constitutions as well as technical and legal aspects of the public budgeting. 


\section{References}

Altuğ, F. (1999), Kamu Bütçesi, 1. Baskı, Bursa: Ezgi Kitabevi.

Aksoy, Ş. (1993), Kamu Bütçesi, İstanbul: Filiz Kitabevi.

Axelrod, D. (1995), Budgeting for Modern Government, $2^{\text {th }}$ Edition, St. Martin's Press Inc., New York.

Basic Law for the Federal Republic of Germany. (1949), German Bundestag, Berlin.

Constitution of Ireland. (1937), Published by the Stationery Office, Dublin. http://www.taoiseach.gov.ie/eng/Historical_Information/The_ Constitution/December_2013 - Bhunreacht_na_hEireann_Constitution_Text.pdf

Constitution of Malta. (1964), http://www.partylaw.leidenuniv.nl/party-law

Constitution of the Czech Republic. (1992), http://www.psp.cz/cgi-bin/eng/docs/laws/1993/1.html

Constitution of the Slovak Republic, http://www.legislationline.org/download/action/download/id/1633/file/69fc5e0f45478ca 59b551a3f8e 92.htm/preview

Constitution of the Italian Republic, Senato della Repubblica, Roma, https://www.senato.it/document/repository/istituzione/ costituzione_inglese.pdf

Constitution of the Portuguese Republic. (2005), http://app.parlamento.pt/site_antigo/ingles/cons_leg/Constitution_VII_revisao_ definitive.pdf

Constitution of the Republic of Bulgaria. (1991), http://www.partylaw.leidenuniv.nl/party-law

Constitution of the Republic of Croatia. (2010), Committee on the Constitution, Standing Orders and Political System of the Croatian Parliament, Zagreb.

Constitution of the Republic of Estonia, (1992), http://www.president.ee/en/republic-of-estonia/the-constitution/index.pdf

Constitution of the Republic of Slovenia, http://www.legislationline.org/

French Constitution of October 4 1958, http://www.assemblee-nationale.fr/english/

Edizdoğan, N., Çetinkaya, Ö. \& Gümüş, E. (2011), Kamu Maliyesi, 3. Baskı, Bursa: Ezgi Kitabevi.

Esen, B.N. (1957), Anayasa Hukuku ve Siyasi Hukuk, Nebioğlu Yayınevi, Ankara.

Federal Constituional Law of Austria (2014), Federal Law Gazette, Wien.

Feyzioğlu, B.N. (1981), Nazari, Tatbiki ve Mukayeseli Bütçe, 6. Baskı, İstanbul: Filiz Kitabevi.

Gözübüyük, Ş. (2013), Anayasa Hukuku, 19. Bası, Turhan Kitabevi, Ankara.

Grotke, K.L. \& Prutsch, M.J. (Ed.), (2014), Constitutionalism, Legitimacy, and Power: Nineteenth-Century Experiences, Oxford University Press, New York.

Kaboğlu, I.Ö. (2014), Anayasa Hukuku Dersleri (Genel Esaslar), 9. Baskı, Legal Kitabevi, İstanbul.

Lee, D.R., Jonhson \& R.W., Joyce, P.G. (2004), Public Budgeting Systems, Seventh Edition, Jones and Bartlett Publishers, London.

Luxembourg's Constitution of 1868 with Amendments through 2009, https://www.constituteproject.org/constitution/Luxembourg_2009.pdf Lyden, F.J. \& Lindenberg, M. (1983), Public Budgeting in Theory and Practice, Longman Inc, New York.

McLeay, E. (2011), Reconstituting the Constitution, In: Morris C., Boston, J \& Butler P. (eds.), Building the Constitution: Debates; Assumptions; Developments 2000-2010 (pp. 3-34), Springer Science \& Business Media, New York.

Mueller, D.C. (2005), Constitutional Political Economy in the European Union, Public Choice, 124, 57-73.

Mutluer, K., Öner, E. \& Kesik, A., (2006), Bütçe Hukuku, 2. Baskı, İstanbul: İstanbul Bilgi Üniversitesi Yayınları 99.

My Constitutional Act With Explanations, Folketinget, Copenhagen, http://www.ft.dk/Dokumenter/Publikationer/Engelsk/ /media/ Pdf_materiale/Pdf_publikationer/English/My\%20Constitutional\%20Act_with_explanations\%20pdf.ashx

Nice, D. (2002), Public Budgeting, Wadsworth Group, Belmont.

O'Regan, D. (2004), Auditor's Dictionary: Terms, Concepts, Processes, and Regulations, John Wiley \& Sons Inc., New Jersey.

Özbudun, E. (2014), Türk Anayasa Hukuku, 15. Baskı, Yetkin Yayınları, Ankara.

Özer, A. (2010), Anayasa Hukuku: Genel İlkeler, 4. Baskı, Turhan Kitabevi, Ankara.

Parpworth, N. (2014), Constitutional nad Administrative Law, Oxford University Press, $8^{\text {th }}$ Edition, New York.

Prosser, T. (2014), The Economic Constitution, $1^{\text {th }}$ Edition, Oxford University Press, New York.

Rubin, I. S. (1997), In:Golembiewski R.T. \& Rabin J. (eds.), Public Budgeting and Finance, Forsth Edition, Budgeting: Theory and Concepts (pp. 185-201), Marcel Dekker Inc., New York.

Somma, A. (2013), Private Law as Biopolitics: Ordoliberalism, Social Market Economy, and the Public Dimension of Contract. Law and Contemporary Problems, 76 (2), 105-116.

Sönmez, N., (1994), Kamu Bütçesi ve Bütçe Politikası, İzmir.

Steiss, A.W. (1972), Public Budgeting and Management, D.C. Heath and Company Lexington, Canada. ,

Teziç, E. (2014), Anayasa Hukuku, 17. Bası, Beta Basım A.Ş., İstanbul.

The Belgian Constitution. (2012), Legal Department of the Belgian House of Representatives - Belgian State Gazette, Brussels.

The Constitution of Greece. (2008), Hellenic Parliament's Publications Department, Greece. http://www.hellenicparliament.gr/UserFiles/ f3c70a23-7696-49db-9148-f24dce6a27c8/001-156\%20aggliko.pdf

The Constitution of Finland. (1999), Ministry of Justice, Finland. http://www.finlex.filfi/laki/kaannokset/1999/en19990731.pdf

The Constitution of Romania, http://www.legislationline.org/download/action/download/id/1630/file/e3b89dda11209ec032c71c1a36a7. $\mathrm{htm} /$ preview

The Constitution of the Kingdom of the Netherlands. (2008), Published by the Ministry of the Interior and Kingdom Relations, http://www.government.nl/ 
The Constitution of the Kingdom of Sweden. (2008), ISN, Zurich, www.partylaw.leidenuniv.nl

The Constitution of the Republic of Latvia, http://www.saeima.Iv/en/legislation/constitution

The Constitution of the Republic of Lithuania, http://www.legislationline.org/download/action/download/id/1597/file/f589d1f7c716bbf6f67 ed6b6b6ce.htm/preview

The Constitution of the Republic of Poland. (1997), http://www.legislationline.org/documents/action/popup/id/16683/preview

The Fundamental Law of Hungary. (2011), The Ministry of Public Administration and Justice, http://www.mfa.gov.hu/NR/rdonlyres/ 8204FB28-BF22-481A-9426-D2761D10EC7C/0/FUNDAMENTALLAWOFHUNGARYmostrecentversion01102013.pdf

The Spanish Constitution. (1978), http://www.congreso.es/portal/page/portal/Congreso/Congreso/Hist_Normas/Norm/const_espa_ texto_ingles_0.pdf

Tüğen, K., (2005), Devlet Bütçesi, 4. Baskı, İzmir.

Willoughby, K.G. (2014), Public Budgeting in Tontext-Structure, Law, Ferorm, and Results, Jossey-Bass, San Francisco.

\section{Tables}

Table 1. The Constitutional Budgeting in European Union Countries in the light of the Modern Budgeting Principles

\begin{tabular}{|c|c|c|c|c|c|c|c|c|c|c|}
\hline & \multicolumn{10}{|c|}{ The Name of the Principle } \\
\hline Country Name & PP & PC & PA & PAN & $\mathrm{AE}$ & PPA & PE & PEC & PCO & PU \\
\hline Austria & $\sqrt{ }$ & & $\sqrt{ }$ & $\sqrt{ }$ & & $\sqrt{ }$ & $\sqrt{ }$ & $\sqrt{ }$ & & $\sqrt{ }$ \\
\hline Belgium & $\sqrt{ }$ & & & $\sqrt{ }$ & & $\sqrt{ }$ & & & $\sqrt{ }$ & \\
\hline Bulgaria & & & & & & $\sqrt{ }$ & & & & \\
\hline Croatia & & & & & & $\sqrt{ }$ & & & $\sqrt{ }$ & \\
\hline Czech Republic & - & - & - & - & - & - & - & - & - & - \\
\hline Denmark & & & & $\sqrt{ }$ & & $\sqrt{ }$ & & & & \\
\hline Estonia & & & & $\sqrt{ }$ & & $\sqrt{ }$ & & & & \\
\hline Finland & & & & $\sqrt{ }$ & & $\sqrt{ }$ & & & $\sqrt{ }$ & \\
\hline France & & & & $\sqrt{ }$ & & $\sqrt{ }$ & & & & \\
\hline Germany & & & & $\sqrt{ }$ & $\sqrt{ }$ & $\sqrt{ }$ & $\sqrt{ }$ & & $\sqrt{ }$ & $\sqrt{ }$ \\
\hline Greece & & & & $\sqrt{ }$ & & $\sqrt{ }$ & & & $\sqrt{ }$ & \\
\hline Hungary & $\sqrt{ }$ & $\sqrt{ }$ & $\sqrt{ }$ & $\sqrt{ }$ & $\sqrt{ }$ & $\sqrt{ }$ & $\sqrt{ }$ & $\sqrt{ }$ & & \\
\hline Ireland & & & & $\sqrt{ }$ & & $\sqrt{ }$ & & & & \\
\hline Italy & & & & $\sqrt{ }$ & & $\sqrt{ }$ & & & & \\
\hline Latvia & & & & $\sqrt{ }$ & & $\sqrt{ }$ & & & & \\
\hline Lithuania & & & & $\sqrt{ }$ & & $\sqrt{ }$ & & & & \\
\hline Luxemburg & & & & $\sqrt{ }$ & & $\sqrt{ }$ & & & $\sqrt{ }$ & \\
\hline Malta & & & & $\sqrt{ }$ & & $\sqrt{ }$ & & & $\sqrt{ }$ & \\
\hline Netherlands & & & & $\sqrt{ }$ & & $\sqrt{ }$ & & & & \\
\hline Poland & & & & $\sqrt{ }$ & & $\sqrt{ }$ & & & & \\
\hline Portugal & & & & $\sqrt{ }$ & & $\sqrt{ }$ & & & $\sqrt{ }$ & \\
\hline Romania & & & & $\sqrt{ }$ & & $\sqrt{ }$ & & & & $\sqrt{ }$ \\
\hline Slovakia & & & & & & $\sqrt{ }$ & & & & \\
\hline Slovenia & & & & & & & & & $\sqrt{ }$ & \\
\hline Spain & & & & $\sqrt{ }$ & & $\sqrt{ }$ & & & $\sqrt{ }$ & \\
\hline Sweden & & & & $\sqrt{ }$ & & $\sqrt{ }$ & & & & \\
\hline
\end{tabular}

This table prepared in the light of the budgetary provisions of EU member states constitutions. 